\title{
THE EFFECT OF THE EUROPEAN UNION BIOMASS REGULATION AND EXPORT TAXATION ON PALM OIL EXPORT
}

\author{
Azwar Annas")1, Suharno*), and Rita Nurmalina*) \\ *) Department of Agribusiness, Faculty of Economics and Management, IPB University \\ Jl. Agatis, Campus of IPB Darmaga Bogor 16680, Indonesia
}

\begin{abstract}
The European Union is one of the world's largest markets for palm oil products. This study used the gravity models theory to analyze the potential changes of palm oil trade flow from Indonesia and Malaysia with a focus destination countries to the European Union. The focus of the study is to analyze the decreasing or increasing trade flow of palm oil due to the biomass regulation changes in the European Union and the export tax on palm oil. The research model involved 85 percent of the global palm oil market which is 61 countries of refined palm oil (RPO) consumers and 23 countries of crude palm oil (CPO) consumers over the period dating from 2006 to 2018. The two types of palm oil export products are clearly distinguished to see the different changes in both types of products trade flow due to the influential factors. The gravity model for analyzing data uses OLS and PPML regression. The results show that the CPO export tax has a significant positive impact on RPO exports but does not have a significant impact on CPO exports. Similar analysis results occur in the variable of biomass regulation change in the European Union, which has a significant negative impact on RPO exports but does not have a significant impact on CPO exports.
\end{abstract}

Keywords: biodiesel, biomass regulation, export tax, gravity model

\begin{abstract}
Abstrak: Uni Eropa adalah salah satu pasar terbesar produk minyak kelapa sawit dunia. Penelitian ini menggunakan teori model gravity untuk menganalisis potensi perubahan aliran perdagangan minyak kelapa sawit dari Indonesia dan Malaysia dengan fokus negara tujuan ke Uni Eropa. Fokus penelitian adalah menganalisis terjadinya pengurangan atau peningkatan aliran perdagangan minyak kelapa sawit akibat perubahan peraturan biomassa di Uni Eropa dan pajak ekspor minyak kelapa sawit. Model penelitian melibatkan 85 persen pasar minyak kelapa sawit global yaitu 61 negara pengkonsumsi refined palm oil (RPO) dan 23 negara pengkonsumsi crude palm oil (CPO) dengan periode data dari tahun 2006 hingga 2018. Kedua jenis produk ekspor minyak kelapa sawit dibedakan dengan jelas untuk melihat perbedaan perubahan aliran perdagangan kedua jenis produk akibat faktor yang berpengaruh. Model gravity untuk menganalisis data menggunakan regresi OLS dan PPML. Hasil analisis menunjukkan bahwa pajak ekspor CPO memberikan dampak positif signifikan pada ekspor RPO namun tidak memberikan dampak signifikan pada ekspor CPO. Hasil analisis yang mirip ditemui pada variabel perubahan regulasi biomass di Uni Eropa yaitu berdampak negatif signifikan pada ekspor RPO namun tidak memberikan dampak signifikan pada ekspor CPO.
\end{abstract}

Kata kunci:biodiesel, regulasi biomassa, export tax, model gravity

\footnotetext{
${ }^{1}$ Corresponding author:

Email: azwar.ann@gmail.com
} 


\section{INTRODUCTION}

Palm oil is an important product export for Indonesia and Malaysia, which are two countries of the largest palm oil producers. For Indonesia, the export of palm oil takes over $9.8 \%$ of the total export value, which is the largest exported product in the country. Malaysia is the main producer of palm oil that dominates global palm oil export until 2010 before Indonesia surpassed it. Indonesia and Malaysia were able to produce more than $80 \%$ of the world's palm oil supply until 2015 and predicted that they would continue to increase their production then be able to supply $90 \%$ of the world's needs in the future (USDA, 2018). Indonesia and Malaysia are also developing more on the palm oil processing industry to produce various derivative products such as refined palm oil and oleochemicals recently (Rizwan and Rahuman, 2014).

The world consumption of palm oil and its derivatives products are very large and keep increasing since the consumption of palm oil products is not only for food but also for non-food products. The increase is shown by the year 1995 to 2018 that the global consumption of palm oil has risen to $600 \%$ (EPOA, 2018). One of the largest importers of palm oil is the EU, which is the second-largest palm oil consumer after India. The EU is a potential market for palm oil that most of the palm oil consumption is for energy. Timilsina and Shreta (2010) argue that the EU is the largest biodiesel producer in the world, with rapeseed oil and palm oil as the main raw material. For example, Germany, as one of the largest palm oil consumers of the EU member took $47.6 \%$ of total palm oil consumption into energy raw material (FPO 2018). The rest of the needs is for food (23.6\%), animal feed (14.2\%), chemical and pharmacy (12.3\%), and cosmetics, and cleaning materials $(2.3 \%)$.

The EU imports more on crude palm oil (CPO) instead of refined palm oil (RPO) due to the capability to process it by themselves. In opposite, the development of exporting countries in building the $\mathrm{CPO}$ refining industry and its derivative products in Indonesia and Malaysia could reduce the amount of CPO exports to the world, including the EU. Besides, Indonesia and Malaysia also restructure their palm oil export tax to restrict the outflow of palm oil export (Rifin, 2014). In Rifin (2014) studies, the period of changes in $\mathrm{CPO}$ export tax structure in Indonesia is divided into three different periods. The three periods of changes are the period from 1994 to 1997 when the very high export taxes period, from 1997 to 2007 when export taxes were very low, and during 2007 to recent when CPO export taxes are adjusted to product prices. The export tax structure change in Malaysia is explained in Ayatollah et al. (2014) which analyzed the Malaysian export tax of palm oil before the change and after. The $\mathrm{CPO}$ export tax in Malaysia before the change was quite high which is around $23 \%$, then drop to around 0 to $8 \%$ in 2013 . The effect found from the export tax reduction in Malaysia is the improvement of Malaysian $\mathrm{CPO}$ export.

It is known that the higher export tax of commodities will reduce the amount and export value, vice versa. The export tax policy is a policy that has a direct impact on trade, especially for the exporter. The results in Ayatollah et al. (2014) research had similar indications that the high export tax in $\mathrm{CPO}$ could reduce the amount and value of CPO export as well as in Rifin (2014) and Obadon, Syaukat, and Siregar (2009) studies, vice versa. There are several differences in Ayatollah et al. (2014) that the decreasing export tax in Malaysia could raise domestic consumption besides the increase of export due to the stability of CPO domestic price. That contradicts with Obado, Syaukat, and Siregar (2009) that the palm oil export tax has the power to control domestic price to protect domestic consumers, especially when CPO global price increase. Palm oil export tax in Indonesia is the instrument to prevent the overflow of CPO export and to sustain the domestic supply. Obado, Syaukat, and Siregar (2009) stated that progressive export tax for $\mathrm{CPO}$ export issued by the government of Indonesia in 2007 creates a benefit for CPO domestic consumers but only a normal benefit for producers. That is because the amount of CPO export decrease, although the global price increase (Rifin 2010). On the same topic, Rifin (2014) argued that the period of the Indonesian CPO progressive export tax policy that began in 2007 did not show a significant decrease in CPO export. The progressive export tax policy does not have a significant impact since the $\mathrm{CPO}$ producers do not have a high resistance to progressive export tax, while the tax adjusts to market prices.

The trade flow changes due to the changes in commodity export tax could be found not only in the case of palm oil export but also in other export commodities. For example, Effendi (2016) and Hasibuan and Sayekti (2018) examined the effect of export tax on Indonesian cocoa bean export. Cocoa beans export tax issued to keep the domestic supply of cocoa beans raw material as 
well as in the case of palm oil. It is effective to decrease the outflow of the cocoa trade and it decreases the competitiveness of the cocoa beans export product. In contrast, the competitiveness of Indonesian derivative products of cocoa is increase. Other research on commodity export tax effect is studied by Rude and An (2015) that found the export tax on food commodities is not always creating price volatility. Many kinds of research on export tax has a similar result on reducing export competitiveness when export tax increase, although some commodity cases face insignificant effect.

Nowadays, biofuel manufacture in the EU is one of the determinant factors of the vegetable oil market in the EU since the trend of using renewable raw materials keeps increasing. This issue could increase the EU consumption on palm oil since it is one of the vegetable oil that the production is huge. However, it also could be a potential market decrease due to the lack of standard compliance. Renewable energy production in the EU related to palm oil is the adoption of biodiesel as a fuel to reduce greenhouse gas (GHG) emission. The EU has a target of reducing $30 \%$ of GHG emissions until 2030 and at least $20 \%$ by each country member by the end of 2020 (EU 2009). In this commitment, including the use of renewable fuels, which is biodiesel for transportation to reach $10 \%$ of the total fuel. After the commitment in 2009, the EU produced more than 10 billion liters of biodiesel with domestic consumption of more than 13 billion liters (USDA, 2013). The biodiesel production in the EU rose to 14 billion liters of production with the consumption is more than 14.5 billion in 2015 (USDA, 2017). Rajcaniova, Drabik, and Ciaian (2013) state that the GHG reduction mandate in the EU is important to determine the movement of biodiesel industries in the country.

The market potential for biodiesel in the EU is increasing indeed, but the palm oil should fulfill the standard compliance to becoming raw material. The standard for biodiesel raw material is regulated by the European Commission, called Fuel Quality Directive 2009/30 (EU, 2009), in which the raw material should be able to produce GHG saving at least $35 \%$ than fossil fuel. For palm oil, biodiesel is still within the range, but it is smallest than the other raw materials. Since the commitment is to reduce GHG emissions as much as possible, it could be a market reduction potential for palm oil as a renewable raw material by the EU, then replaced by another vegetable oil. On the other side, the
EU has a good technology to process palm oil to become good biodiesel that meets the high requirements. That could be a chance to export palm oil as a raw material by the producing countries since the productivity of palm oil is better compared to other vegetable oil.

Biomass regulation in the $\mathrm{EU}$ can be potentially discriminate against the entry of trade flows for a certain product. This kind of policy recognized as the NTB (non-tariff barrier trade) policy which indirectly influences the cost of a trade. Several studies related to NTB had been recorded, although the research which mentions biomass regulation in the EU trade is difficult to be found. The research regarding the standard of the product seems to have similar results, which are reducing the import or export of the products. The researches by Kuo and Vincent (2018) and Wang, Zhang, and Zeng (2016) state that the influence of environmental regulation that is related to the trade could give more standard conditions to enter the market in a certain country. Their studies show a significant decrease in trade, which the standard change into more difficult to comply with. Kareem (2016) also found the reason for the negative effect of the EU fish regulation standards on fish exports from Africa that the new high standard has a high cost of compliance.

Based on the case of the existence of export tax and biomass regulation in the EU that explained above, this study intends to analyze the potential import decreasing or increasing on palm oil trade due to the EU biomass regulation and palm oil export tax changes. The analysis is using the gravity model with the regression of ordinary least square (OLS) as suggested by Anderson and van Wincoop (2003) and Poisson-pseudo maximum likelihood (PPML) suggested by Silva and Tenreyro (2006).

\section{METHODS}

The data for this study used a secondary data panel of palm oil trade data HS 151110 for crude palm oil (CPO) and data HS 151190 for refined palm oil (RPO) from Indonesia and Malaysia. The data of palm oil trade from the two major exporting countries, Indonesia and Malaysia, has accounted for more than $80 \%$ of the world's palm oil total export. The main partner of palm oil exporter in this research is the EU that applies the biomass regulation. Other palm oil consumers outside the EU will be included and the sum of the 
EU consumption plus other nation consumption will represent at least $85 \%$ of the total trade value of palm oil from the two main palm oil-producing countries.

Time series data is annual data that starts from 2006 to 2018 while cross-section data consists of data from palm oil-importing countries. Secondary data used in this study were obtained from various sources. The determinant factors used in this study are intended for specific commodities that are only related to palm oil trade. Based on this case, import value is specifically the value of CPO or RPO imports as the dependent variable. The palm oil production represents the economic mass of exporters while the economic mass of importers represented by the real GDP of each country. GDP of importers is chosen as an indicator since it is a better predictor for potential demand and supply compare to population data (Bosse, 2013) The use of annual palm oil production to be exporter's economic mass representative because this research only explains one specific commodity related to international trade. There are 61 RPO importing countries and $23 \mathrm{CPO}$ importing countries listed in the analysis. The export tax data in the analysis is the relative export tax data obtained by calculating the export tax issued on CPO relative to the RPO export tax. Relative export tax equation is as follows:

\section{Relative export tax $=(1+\mathrm{CPO}$ export tax $) /(1+\mathrm{RPO}$ export tax) (Eq. 1)}

The use of relative export tax is caused by the presence of export taxes on both $\mathrm{CPO}$ and RPO commodities, while the RPO export tax is only applied in Indonesia with a very small percentage. Based on this, the analysis will be the search for export tax change on CPO, which can reflect more impact than the RPO export tax. Palm oil export tax structure in Indonesia and Malaysia has changed over ten years from 2006 to 2018. Besides, monthly palm oil export tax is released by the authority while this research needs to use the annual palm oil export tax data. Due to these changes and the absence of annual export tax data, the export tax needs to be calculated manually based on the tariff released every month. The formula for calculating palm oil annual export tax is as follows:

Anmual export tax $=\sum \frac{\text { monthly production }}{\text { yearly production }} \times$ monthly tariff $\quad($ Eq. 2)
Biomass regulation data refers to the EU's commitment to climate change, which actively attempts to reduce greenhouse gas (GHG) emissions. The commitment of $20 \%$ GHG reduction in the EU has been started since 2009, as stated in the Renewable Energy Directive 2009/28/EC and Fuel Quality Directive 2009/30/ EC (EU, 2009). This commitment follows the Kyoto Protocol commitment, which is to reduce global GHG emission in 2008 by $5 \%$ while the EU commits to reducing GHG more than the Kyoto Protocol target. Therefore, the data used for biomass regulation is a binary data variable that refers to the changes in the EU regulations that begin in 2009 .

The distance factor is known in the gravity model theory as a negative factor opposite to economic mass. The distance data in the gravity model is a proxy of transportation costs. The distance variable means the distance between two countries based on bilateral distances between the biggest cities of those two countries that calculated by the share of the city in the overall country's population (Mayer and Zignago, 2006). Besides, several data variables that can affect trade between countries are included in this research to create the analysis less biased. Some of these data are an import tax, colony, and common language. The import tariff or tax is a duty applied to the imported commodity as the cost to enter a certain country. It has a potential reduction in demand since it creates the price of a commodity is higher. Colony and Common Language data explain geographical closeness based on cultural similarities. The colony data explains the closeness between the exporting and importing countries based on colonialism in the past. The common language data explains the closeness between countries based on the languages' similarity that the users of the same language in both countries reach the minimum percentage of 20 percent.

Analysis for this research is using a gravity model that uses ordinary least square (OLS) regression and Poisson-pseudo maximum likelihood (PPML). The use of an OLS estimator on gravity models is the early method of application to analyze the trade using gravity model like in Anderson (1979), Anderson and van Wincoop (2003), and in equation Baldwin and Taglioni (2006). It is also often used in the latest time, which of course appropriate with the research needs as in Yang and Martinez-Zarzoso (2014), who compared the results of pooled OLS analysis with OLS fixed effects on ASEAN-China free trade. Besides, some 
linear OLS estimation models also do not require a natural logarithm when the variables do not contain the risk of heteroskedasticity or bias. As in Kareem's (2016) study, which only involved dummy variables of regulatory and vector pair, otherwise the trade cost of commodity standards.

Three conditions are needed when we use the OLS estimator on the gravity model so that the estimation results are statistically less biased. These conditions are orthogonality assumption, homoscedasticity assumption, and the full rank assumption (Shepherd, 2016). As suggested by Anderson and van Wincoop (2003), the inclusion of multilateral resistance will overcome the problem of heteroscedasticity, which the problem mostly arises in the OLS model of trade. This study does not include multilateral resistance and time effect due to the range of data that is only focused on Indonesia and Malaysia as exporters of palm oil. Besides, the commodity data for this research only specific on palm oil trade data. The problem of heteroscedasticity can be deal with PPML, as suggested by Silva and Tenreyro (2006). The use of OLS and PPML is to compare the results and their consistency by both methods. The Breusch-Pagan test was used to detect the heteroscedasticity in the OLS model (Breusch and Pagan, 1979) or look for the plot of the OLS data. Meanwhile, PPML was introduced by Silva and Tenreyro (2006) as an alternative way to analyze gravity models without ignoring zero-trade, and it is a good estimator to control heteroscedasticity.

In this study, to analyze the effect of EU regulation and export tax on the palm oil trade will using the gravity equation. The panel data provided will be analyzed using linear regression pooled OLS estimator and nonlinear regression PPML estimator. The OLS gravity equation will use the natural logarithm to overcome the problem of heteroscedasticity due to elasticity in trade data. However, the natural logarithm result in the loss of the zero-trade effect since $\log (0)$ is undefined. To overcome the issue of zero in trade data, it can be added $(+1)$ since $\log (1)$ is zero. With the variables determined, the gravity equation for OLS estimation is as follows:

$$
\begin{aligned}
\ln \left(\mathrm{M}_{\mathrm{ijt}}\right)= & \beta_{0}+\beta_{1} \operatorname{lnGDP}_{\mathrm{it}}+\beta_{2} \ln \operatorname{Prod}_{\mathrm{jt}}+\beta_{3} \operatorname{lnDist}_{\mathrm{ij}}+ \\
& \beta_{4} \ln \operatorname{Imptax}_{\mathrm{it}}+\beta_{5} \ln \operatorname{Rexptax}_{\mathrm{jt}}+\beta_{6} \text { Colony }_{\mathrm{ij}}+ \\
& \beta_{7} \text { Language }_{\mathrm{ij}}+\beta_{8} \text { Bio }_{\mathrm{it}}+\varepsilon_{\mathrm{ijt}} \text { (Eq. 3) }
\end{aligned}
$$

Then, the PPML estimator is one of the good methods and is widely used in gravity models. The PPML does not ignore the existence of zero trade when log-linear OLS ignores it. Sheperd (2016) argues that PPML is able to represent policy impact better than OLS. Silva and Tenreyro (2011) also prove their first theory that the PPML estimator is consistent and better to counter the problem of heteroscedasticity than GPML (gammapseudo maximum likelihood) and also gives lower bias than OLS. The PPML equation in this study is as follows:

$$
\begin{aligned}
\mathrm{M}_{\mathrm{ijt}}= & \exp \left\{\beta_{0}+\beta_{1} \operatorname{lnGDP}_{\mathrm{it}}+\beta_{2} \ln \operatorname{Prod}_{\mathrm{jt}}+\beta_{3} \operatorname{lnDist}_{\mathrm{ij}}\right. \\
& +\beta_{4} \operatorname{lnmptax}_{\mathrm{it}}+\beta_{5} \operatorname{lnRexptax}_{\mathrm{jt}}+\beta_{6} \text { Colony }_{\mathrm{ij}}+ \\
& \left.\beta_{7} \text { Language }_{\mathrm{ij}}+\beta_{8} \text { Bio }_{\mathrm{it}}\right\} \cdot \varepsilon_{\mathrm{ijt}}(\text { Eq. } 4)
\end{aligned}
$$

where the dependent variable, $\mathrm{M}_{\mathrm{ijt}}$ indicates bilateral imports from the country i import commodity from the country $\mathrm{j}$ in period $\mathrm{t}$ at current US\$. GDP ${ }_{\mathrm{it}}$ is the level of nominal gross domestic product in importing countries $\mathrm{i}$ in period t. Prod $_{\mathrm{jt}}$ is the palm oil production from the exporters $j$ with the weight size tonnes. GDP $_{\text {it }}$ and $\operatorname{Prod}_{\mathrm{jt}}$ variables denote the economic levels of a country and are likely to have positive relationships with trade flows. Dist ${ }_{\mathrm{ij}}$ indicates the economic distance between importing countries $i$ and exporting countries $j$, as a proxy of transportation cost. In opposite with GDP $_{\text {it }}$ and $\operatorname{Prod}_{\mathrm{jt}}$ variables, Dist ${ }_{\mathrm{ij}}$ variable is likely to have a negative impact on trading flow. Imptax $_{\text {it }}$ variable is the import tax applied in importing countries while variable $\operatorname{Rexptax}_{\mathrm{jt}}$ is the relative export tax of CPO and RPO issued in exporting countries. Imptax ${ }_{i t}$ and

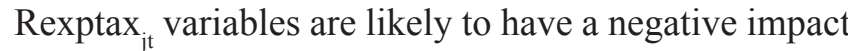
to the palm oil commodity trade. Variable Colony ${ }_{\mathrm{ij}}$ is a binary variable as well as variable Language ${ }_{i j}$ to represent the cultural closeness between importing and exporting countries based on the historical relation and common language. Both variables could have a positive effect since the closer of relation, the trade of palm oil could become higher. $\mathrm{Bio}_{\mathrm{it}}$ indicates a binary variable of biomass regulation change in the EU since 2009. Variable $\mathrm{Bio}_{\text {it }}$ indicates non-tariff measure that has a negative effect on the trade between countries.

\section{RESULTS}

Based on the background, the research intends to detect the effects of biomass regulation and palm oil export tax on the trade of palm oil from Indonesia and Malaysia, the two largest palm oil-exporting countries. For this 
purpose, the gravity model is used since the gravity model has a good quality of policy explanation. In this study, two ways of estimators were carried out, namely by using OLS linear regression and PPML estimator. Palm oil products are separated into two major palm oil products which are RPO (HS 151190) and CPO (HS 151110), to explain the different implications from the determinant factors. The use of separate data between CPO and RPO is to detect the different effects that possibly occur since the different use of both products. The data of all variables gather for 61 countries of RPO importer and 23 countries of CPO importer. That number of countries, including the EU which are 17 countries of RPO importer and 11 countries of CPO importer. All data is secondary data gathered from various data sources. For the data of palm oil export tax is difficult to obtain, then this research obtains from various journals, official websites, and organizations. The export taxes from the various resources are raw and in the form of monthly export tax. The conversion of monthly export tax to be annual export tax is using Eq. 2. The result is showed in Table 1. As in the Eq.3 and Eq.4, the variable used is the relative export tax $\left(\operatorname{Rexptax}_{\mathrm{jt}}\right)$, which is the relative $\mathrm{CPO}$ export tax in comparison with RPO export tax. The variable relative export tax could be calculated after knowing the annual export tax in Table 1, then calculated with Eq.2. The effect expectation of export tax is when the tax increase, it will decreasing the palm oil export, vice versa. From the export tax obtained in Table 1, then the relative export tax can be calculated using Eq. 1.

Gross domestic product (GDP) of importer explained as the economic mass of the importing country. Since the dependent variable is the palm oil import value from the importing country, the impact should be positive when the importer's GDP increase. On the exporter side, namely Indonesia and Malaysia, the economical mass cannot be directly described by GDP because trade is carried out specifically for palm oil exports, which only take a small percentage of GDP. Therefore, this study used the total production of palm oil as a measure of economic mass or the potential of palm oil supply from the exporter. The hypothesis for this variable is producing a positive impact since the increase of palm oil production will increase the export potential. Import tax of palm oil products from importers are included to measure the impact of import tax on palm oil exports when import tax varies in each partner country. In addition, this study also involves common language and colony variables so that trade factors become widespread, and it is expected that the magnitude obtained can imply the actual situation.

Table 1. Indonesia and Malaysia palm oil export tax development in 2006 to 2018 (\%)

\begin{tabular}{ccccc}
\hline \multirow{2}{*}{ Year } & \multicolumn{2}{c}{ Indonesia } & \multicolumn{2}{c}{ Malaysia } \\
\cline { 2 - 5 } & RPO & CPO & RPO & CPO \\
\hline 2006 & 0 & 1.50 & 0 & 21.80 \\
2007 & 0 & 4.40 & 0 & 21.80 \\
2008 & 0 & 9.47 & 0 & 21.80 \\
2009 & 0 & 0.70 & 0 & 21.80 \\
2010 & 0 & 5.70 & 0 & 22.90 \\
2011 & $6.92 \times 10^{-4}$ & 18.70 & 0 & 22.10 \\
2012 & $5.94 \times 10^{-2}$ & 14.83 & 0 & 3.70 \\
2014 & $3.10 \times 10^{-2}$ & 9.63 & 0 & 3.55 \\
2015 & $4.56 \times 10^{-2}$ & 8.38 & 0 & 0.13 \\
2016 & 3.68 & 1.53 & 0 & 3.70 \\
2017 & 7.90 & 7.99 & 0 & 6.56 \\
2018 & 6.07 & 4.81 & 0 & 3.38
\end{tabular}

Note: Author's calculation by elaborating the export tax data changes from Ayatollah et al. (2014), Rifin (2010 \& 2014), from https://www.kemendag.go.id/, http://bepi.mpob.gov.my/ and the export value from https://www.wto.org/. 


\section{OLS Estimation}

Based on the data specifications explained, this research applies the data into a data panel to estimate the effect of EU biomass regulation and export tax on palm oil exports. The estimation is done using OLS estimation and PPML estimation. The OLS estimation results show that the gravity equation is consistent with many previous studies which showed that GDP $_{\text {it }}$ has a significant positive effect on trade. $\mathrm{n}$ this study, the higher GDP of importers will positively affect the consumption of palm oil, RPO and CPO. Dist ${ }_{\mathrm{ij}}$ variable also shows the same consistent results that distance has a negative influence on trade. Based on OLS estimation results in Table 2, OLS estimation gives different results between RPO and $\mathrm{CPO}$ commodities in the
$\operatorname{Prod}_{\mathrm{jt}}$ variable. A significant positive number is found in RPO commodity trade, whereas in CPO commodity does not show a statistically significant number. This means that the increase in palm oil-producing countries has an impact on RPO consumption internationally more than CPO. Perhaps it is because the palm oil production in exporting countries produces more on RPO based on the data of this study. Almost all the factors in OLS estimation of RPO commodity give a positive significant number except for the Dist $t_{i j}$ and $\mathrm{Bio}_{\mathrm{it}}$. Including the variables of Rexptax $\mathrm{jt}_{\mathrm{jt}}$ and Imptax also show positive significance statistically. In OLS estimation results of CPO commodity does not show statistically significant in $\operatorname{Rexptax}_{\mathrm{jt}}$ variable and $\mathrm{Bio}_{\mathrm{it}}$ variable. That means the change of both variables does not affect the CPO commodity trade.

Table 2. OLS estimation results

\begin{tabular}{|c|c|c|}
\hline & \multicolumn{2}{|c|}{ Dependent variable } \\
\hline & $\ln \mathrm{RPO}_{\mathrm{ijt}}$ & $\ln \mathrm{CPO} \mathrm{M}_{\mathrm{ijt}}$ \\
\hline \multirow[t]{2}{*}{$\overline{\ln \mathrm{GDP}_{\text {it }}}$} & $0.558 * * *$ & $0.330 * * *$ \\
\hline & $(0.032)$ & $(0.088)$ \\
\hline \multirow[t]{2}{*}{$\ln \operatorname{Prod}_{\mathrm{jt}}$} & $1.066^{* * *}$ & 0.298 \\
\hline & $(0.242)$ & $(0.472)$ \\
\hline \multirow[t]{2}{*}{$\ln$ Dist $_{\mathrm{ij}}$} & $-0.908 * * *$ & $-0.468 * *$ \\
\hline & $(0.113)$ & $(0.200)$ \\
\hline \multirow[t]{2}{*}{$\ln \operatorname{Imptax}_{\mathrm{it}}$} & $2.288 * * *$ & $5.174 * * *$ \\
\hline & $(0.726)$ & $(0.890)$ \\
\hline \multirow[t]{2}{*}{$\ln \operatorname{Rexptax}_{\mathrm{jt}}$} & $3.384 * * *$ & 1.644 \\
\hline & $(0.821)$ & $(1.545)$ \\
\hline \multirow[t]{2}{*}{ Colony $_{\mathrm{ij}}$} & $1.136^{* *}$ & $1.548 * * *$ \\
\hline & $(0.445)$ & $(0.514)$ \\
\hline \multirow[t]{2}{*}{ Language $_{\mathrm{ij}}$} & $0.878^{*}$ & $-1.593 * *$ \\
\hline & $(0,480)$ & $(0.629)$ \\
\hline \multirow[t]{2}{*}{$\mathrm{Bio}_{\mathrm{it}}$} & $-1.148 * * *$ & -0.140 \\
\hline & $(0.149)$ & $(0.295)$ \\
\hline \multirow[t]{2}{*}{ Constant } & $-8.052 *$ & 6.941 \\
\hline & $(4.311)$ & $(8.679)$ \\
\hline Observations & 1484 & 526 \\
\hline $\mathrm{R}^{2}$ & 0.252 & 0.156 \\
\hline Adjusted $\mathrm{R}^{2}$ & 0.248 & 0.143 \\
\hline Residual Std. Error & $2.201(\mathrm{df}=1475)$ & $2.481(\mathrm{df}=517)$ \\
\hline F Statistic & $62.246^{* * *}(\mathrm{df}=8 ; 1475)$ & $11.934 * * *(\mathrm{df}=8 ; 517)$ \\
\hline
\end{tabular}

Note: $\quad * \mathrm{p}<0.1 ; * * \mathrm{p}<0.05 ; * * * \mathrm{p}<0.01$ 
OLS estimation shows that import tax given by the importer on RPO and CPO commodities has a positive impact on their consumption and potentially could increase palm oil trade. This is not following the theory shown by Anderson and van Wincoop (2003) that the existence of a trade barrier will create a trade cost so that the greater the trade barrier will create a greater trade cost. When the trade cost gets bigger, then the trade is distorted and imports are lower (Salvatore, 2013). This study found a different result, perhaps because this case is only found in the calculation of palm oil commodity trade since the value of trade is becoming bigger over time, although the import tax may change to be higher.

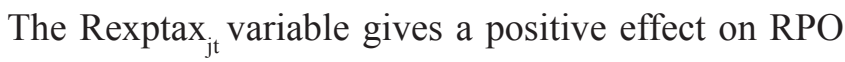
exports and statistically significant but is not statistically significant on CPO exports. The relative export tax describes the export tax of CPO relative to an export tax of RPO. That is why the impact is more on RPO export than CPO. The effect is quite large, which is showed by the coefficient number in the estimation 3.384 , so the average treatment will be 3.384 points higher than the effect of the increase of relative export tax. $\mathrm{Bio}_{\text {it }}$ variables also give a significant number in RPO export. The negative magnitude shows that it will reduce the trade flow for the RPO product. The average treatment of biomass regulation on RPO trade is lowering the trade becomes only $68 \%$ from the normal trade in the EU, ceteris paribus. In the CPO results, it gives a positive effect while it is not statistically significant so that number can be abandoned.

The variables of Colony ${ }_{\mathrm{ij}}$ and Language $\mathrm{i}_{\mathrm{ij}}$ are statistically significant in both products. That means the factor of cultural closeness has an impact on palm oil trade. Although, the number estimated for Language ${ }_{\mathrm{ij}}$ variable is different for RPO and CPO. It has a positive effect on RPO, while it has a negative effect on CPO. The magnitude is quite large more than the magnitude from GDP and distance variables, which means the cultural closeness has a bigger impact on trade. But, this study found the cultural closeness only for several countries, which are Indonesia-Netherland and Malaysia-United Kingdom for colonial history, then Malaysia to Singapore and China for a common language.

The variables used in this article are quite dependable to represents the actual trade. However, if we are looking for the R-squared value, the number is quite small for both products. The number represents that the model of OLS estimation cannot describe the actual condition when it only gives $25 \%$. It probably because the OLS gravity model cannot meet the condition that mentions in Sheperd (2016). Especially for the heteroscedasticity of the panel data of trade that mention by Silva and Tenreyro (2006), it could produce bias that needs to overcome. Silva and Tenreyro (2006) give a better option instead of OLS estimator to handle heteroscedasticity with the PPML estimator.

This study uses two kinds of tests to detect heteroscedasticity in OLS estimator, which are graphical plot and Breusch-Pagan test. First, the graphical plot the results as in Figure 1. The graphical plot in Figure 1 shows that there is heteroscedasticity on the model of CPO trade. It looks like the data in CPO trade is not well scattered and the red line indicates the curve while in RPO trade data shown, the data is well scattered. The Breusch-Pagan test results show that OLS estimation on RPO product is not statistically significant, which expresses by the p-value is larger than 0.05 while the Breusch-Pagan test for OLS estimation on CPO product shows p-value below 0.05 . The BreuschPagan results mean that there is heteroscedasticity in the linear model of the CPO commodity OLS model. Homoscedasticity only found in the linear model of RPO product. Two types of tests show consistent results and no contradicting.

\section{PPML Estimation}

The next result is based on Silva and Tenreyro (2006) recommendation that is using a PPML estimator to overcome heteroscedasticity. The result can be looked at in Table 3. The result also shows the consistent effect

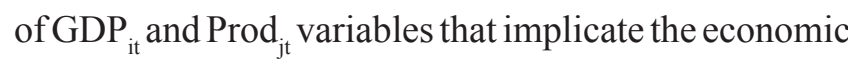
level. Both results give statistically positive significant effects on palm oil trade. Although the magnitude seems stronger on the exporter's side, that showed by the nominal result of Prod jt variables is larger than the nominal of $\mathrm{GDP}_{\mathrm{it}}$. Variable distance is also consistent with the hypothesis that reflects a negative impact on the trade. The magnitude of three variables of $\mathrm{GDP}_{\mathrm{it}}$, $\operatorname{Prod}_{\mathrm{jt}}$, and Dist $\mathrm{ij}_{\mathrm{j}}$ in PPML results are stronger on the RPO side. These results are consistent compared to OLS estimator result that also shows a bigger nominal on RPO side. The effect is larger since the production of RPO in Indonesia and Malaysia is bigger than CPO for the recent year. Besides, the trade value of RPO also exceeds CPO since RPO is more expensive than CPO. 

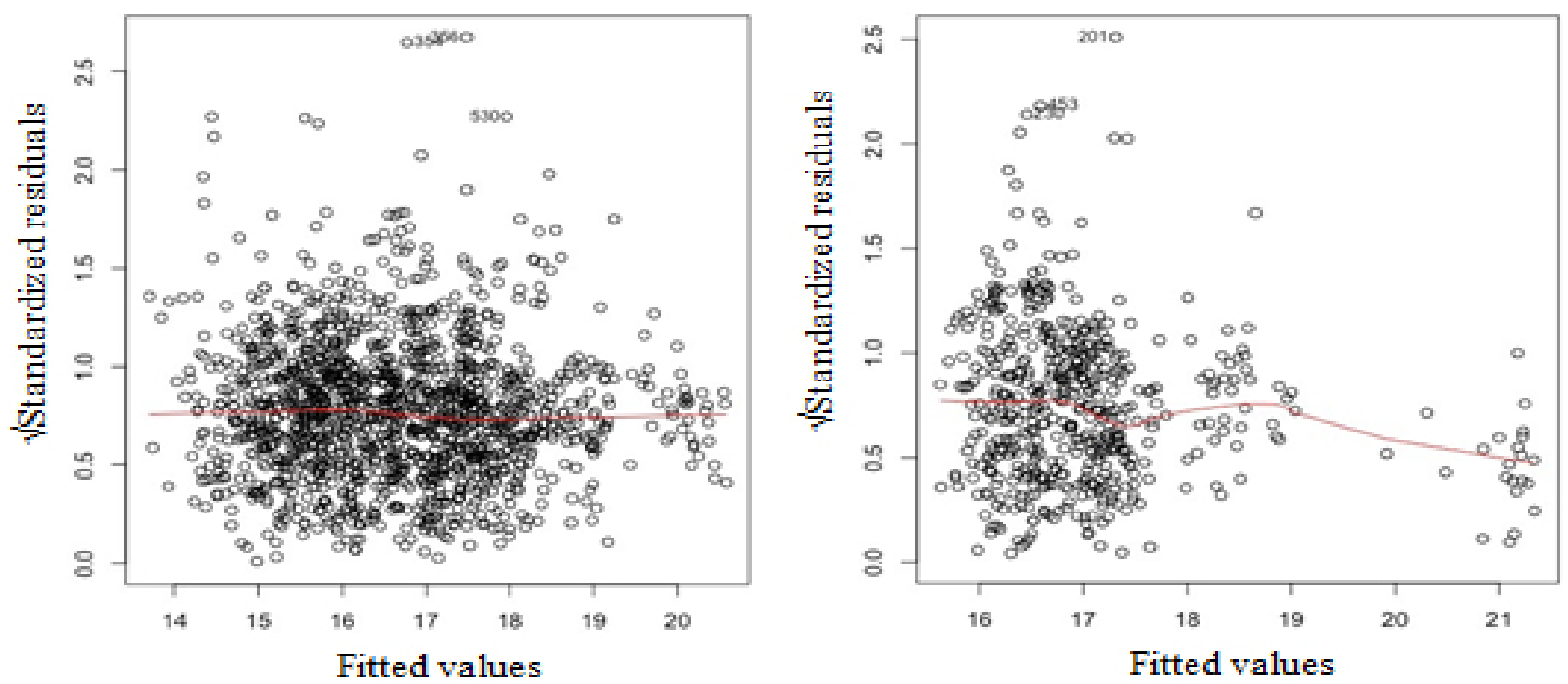

Figure 1. Graphical plot of OLS RPO (left) and CPO (right)

Table 3. PPML estimation results

\begin{tabular}{|c|c|c|}
\hline & \multicolumn{2}{|c|}{ Dependent variable } \\
\hline & RPO $M_{i i t}$ & $\mathrm{CPO} \mathrm{M}_{\mathrm{iit}}$ \\
\hline \multirow[t]{2}{*}{$\ln \mathrm{GDP}_{\mathrm{it}}$} & $0.542 * * *$ & $0.189 * * *$ \\
\hline & $(0.028)$ & $(0.072)$ \\
\hline \multirow{2}{*}{$\ln \operatorname{Prod}_{\mathrm{jt}}$} & $1.623 * * *$ & $0.783 * * *$ \\
\hline & $(0.187)$ & $(0.280)$ \\
\hline \multirow[t]{2}{*}{$\ln$ Dist $_{\mathrm{ij}}$} & $-0.519 * * *$ & $-0.362 * * *$ \\
\hline & $(0.068)$ & $(0.096)$ \\
\hline \multirow[t]{2}{*}{$\ln \operatorname{Imptax}_{\mathrm{it}}$} & $1.483 * * *$ & $3.682 * * *$ \\
\hline & $(0.338)$ & $(0.428)$ \\
\hline \multirow[t]{2}{*}{$\ln \operatorname{Rexptax}_{\mathrm{jt}}$} & $3.587 * * *$ & 1.077 \\
\hline & $(0.698)$ & $(0.970)$ \\
\hline \multirow[t]{2}{*}{ Colony $_{\mathrm{ij}}$} & -0.047 & $0.986 * * *$ \\
\hline & $(0.235)$ & $(0.240)$ \\
\hline \multirow[t]{2}{*}{ Language $_{\mathrm{ij}}$} & $1.068 * * *$ & $-1.260 * * *$ \\
\hline & $(0.185)$ & $(0.371)$ \\
\hline \multirow[t]{2}{*}{$\mathrm{Bio}_{\text {it }}$} & $-1.156 * * *$ & -0.062 \\
\hline & $(0.127)$ & $(0.236)$ \\
\hline \multirow[t]{2}{*}{ Constant } & $-19.240 * * *$ & 3.192 \\
\hline & $(3.261)$ & $(5.660)$ \\
\hline Observations & 1549 & 591 \\
\hline Residual Std. Error & 14920 on $(\mathrm{df}=1540)$ & 20680 on $(\mathrm{df}=582)$ \\
\hline F Statistic & $62.246^{* * *}(\mathrm{df}=8 ; 1475)$ & $11.934 * * *(\mathrm{df}=8 ; 517)$ \\
\hline
\end{tabular}

Note: $\quad * p<0.1 ; * * p<0.05 ; * * * p<0.01$ 
The variable $\operatorname{Imptax}_{\mathrm{it}}$ shows a statistically significant with the positive coefficient. These results indicate the contradiction with the theory of trade barriers in economy. This result similar to the OLS result that the import tax gives a positive magnitude on trade. The interpretation of this result is a $1 \%$ increase of import tax on RPO product from the importers will lead to an increase in import value by $1.48 \%$. Similar interpretation with $\mathrm{CPO}$ products that a $1 \%$ increase in import tax on CPO products will lead to increase import value by $3.68 \%$. Similar to OLS results, PPML results show import tax on CPO gives more impact rather than on RPO. Perhaps, it because of the import tax is less restrictive on CPO compare to RPO.

The condition of import tax data by importing countries is changing over time, but it may less effective compared to the export tax in exporting countries to be a trade barrier. Based on the data of this research, it is true that the import of palm oil products keeps growing over time at a rapid pace. It could be the palm oil import tax from the importing countries is abandon by the consumer since the needs are growing vast. The following effect will create an efficient production in both products produce by exporters who make the importing countries can access the product more than before, although the import tax also higher. The variable $\operatorname{Rexptax}_{\mathrm{jt}}$ of PPML estimation gives a positive coefficient as well as in the OLS estimation result on RPO commodity. The coefficient is slightly larger than in OLS that gives positive 3.58 points higher effect on import value when the relative export tax increase 1 point. The coefficient of relative export tax variable on $\mathrm{CPO}$ product also shows a positive effect in a small magnitude. However, the coefficient is not statistically significant.

The PPML estimation results show that almost all variables are significant on RPO commodity except for the Colony ${ }_{\mathrm{ij}}$ variable. The variable colony on RPO product shows the negative effect, but the magnitude is quite small. Otherwise, this coefficient is not statistically significant. On the other side, colony shows significant positive on CPO commodities with an average increase of up to $168 \%$ higher of the normal trade when the colony is similar. As mention above, Colony $_{\mathrm{ij}}$ in this study refers to Indonesia with the Netherlands and Malaysia with the United Kingdom. The other significant border effect is the Languageij which the coefficient shows consistent results in OLS and PPML estimators. In the RPO products, common variable language gives a positive impact on the import value, which means if the language is the same, the average treatment will give the trade 190\% higher than normal trade. In contrast, the magnitude of CPO products decreases the trade until $71 \%$ from normal import value when the common language is the same. The coefficient of common language variable on CPO is not consistent since several past studies reflect the positive impact of a common language (Yang and Martinez-Zarzoso, 2014, Martinez-Zarzoso, 2013, Sheng et al. 2014). Common language occurs only for Malaysia as the exporter to Singapore and China while there is no common language for Indonesia.

The negative coefficient is shown on $\mathrm{Bio}_{\mathrm{it}}$ variable for both RPO and CPO product estimation. However, the result only shows statistically significant on RPO product. This result consistent with the OLS estimation result. The treatment of biomass regulation to the import value is reducing until becoming $68 \%$ of the normal trade in the EU only. The biomass regulation variable represents the change of regulation within the EU that adopts several standards of producing biodiesel. The standard should meet the target of reducing greenhouse gas. The results of both estimations are significant and negatively reduce the trade for RPO. The significant coefficient means that the exporter experiences a decrease in trade for RPO in the EU because of biomass regulation change. This implies that the $\mathrm{EU}$ is not necessary to use RPO for biodiesel production since the technology within the EU is advanced enough to produce biodiesel from CPO. But, there is no significant result for the coefficient of CPO in OLS and PPML estimation. That implies the import of $\mathrm{CPO}$ products in the EU is not increasing or decreasing significantly because of the change in biomass regulation. Perhaps, that is because the raw material for biodiesel is not CPO only.

The relative export variables coefficient on the result of OLS and PPML estimations are positive and statistically significant on RPO commodities. That is implied that $\mathrm{RPO}$ experiences an increase in trade when the export tax of CPO is bigger. This is a good interpretation since the government issue of CPO export tax is to prevent the outflow trade of CPO (Rifin, 2010; Ayatollah et al. 2014). In opposite, export tax for RPO is far less restrictive than $\mathrm{CPO}$ export tax that could more potential export for RPO. In regards to the studies of Anderson and van Wincoop (2003), Silva and Tenreyro (2006), and Martinez-Zarzoso (2009), this study looks for the 
difference in the result of OLS and PPML estimator in terms of bias. Based on the results in Table 2 and Table 3, it can be seen that Standard Errors produced by both estimations are quite small. That means both of the estimators could be a proper tool to analyze the gravity model in this study.

\section{Managerial Implication}

From the analysis results shown by the two analysis methods, it can be concluded that several factors can affect palm oil trade. From those results, conclusions can be drawn to make good policies to increase the benefit of palm oil international trade. On factors that represent economic mass, the effect of importer GDP and palm oil production is consistent with the gravity model theory by Anderson (1979) which is significantly positive to the trade. Likewise, the distance variable gives a negative effect on the trade so that when the distance is farther away, the trade will decrease.

The focuses of this research are to look for the impact of the EU biomass regulation changes and export taxes on palm oil international trade. The application of biomass regulations in the European Union starting in 2009 led to a decline in palm oil exports of RPO type to the EU. This could be due to the EU becoming more selective in using biodiesel raw material as a commitment to reduce GHG emissions. However, the analysis results did not show a significant increase or decrease in CPO products. Based on that, producers can improve the quality of palm oil production to meet the standards set by the EU in the Fuel Quality Directive 2009/30 (EU 2009). Besides, the opportunity to produce more $\mathrm{CPO}$ and export it to the European Union will be more realistic since biomass regulation does not have a negative impact on $\mathrm{CPO}$.

The analysis results on the export tax show the export tax on CPO will significantly affect RPO exports when the CPO export tax does not have a significant effect on the CPO itself. The policy implication of this result is by increasing the CPO export tax, the RPO export will be increased quite large. The $\mathrm{CPO}$ export tax will restrict the international trade of $\mathrm{CPO}$, while the RPO export will increase since the RPO price is higher than CPO and the RPO export tax is lower. This result agrees with Obado, Syaukat, and Siregar (2009) that the policy of increasing the $\mathrm{CPO}$ export tax will benefit the domestic industry to process from CPO into RPO. The increase in $\mathrm{CPO}$ export tax will trigger the development of the domestic RPO processing industry. Especially at present, the use of palm oil products is already diverse that can even be processed into biodiesel.

In economic theory, export tax and import tax are factors that can distort the trade. However, in this study of palm oil trade, it can be seen that the import tax shows a significant positive value on both palm oil products. This finding states that the import tax applied by the importing country is unable to reduce the flow of palm oil imports. This could be because the palm oil processing industry in the importing countries have been far developed, so that import needs cannot be reduced by increasing import taxes. For palm oil exporters, this condition means that they still have a huge opportunity to increase their production and export for both products. However, the analysis results show the increasing value is greater on the $\mathrm{CPO}$ rather than the RPO.

Other important trade factors are the colony and common language. Policy implication based on these two factors is very difficult to compose when these two factors are very hard to improve. These factors represent bilateral closeness based on culture and history. The closer relation of the countries, the trade will be higher. Based on these factors, common language could be the possibility to increase the trade when the language between bilateral countries becoming similar. For example, if English becomes Indonesian second language, it could increase the palm oil trade to many European Union countries and the USA. In contradict, the colony factor is unable to change.

\section{CONCLUSIONS AND RECOMMENDATIONS}

\section{Conclusions}

This study aims to analyze the effects of changes in biomass regulation in the EU on the palm oil trade, especially for EU import. Besides, this study also aims to analyze the impact of palm oil export tax on the export of palm oil. This study uses the gravity model as a method to search the international trade change of palm oil from Indonesia and Malaysia. The commodity analysis of palm oil is separated between refined palm oil (RPO) and crude palm oil (CPO). The usual variables of the gravity model method are distance, GDP of the importer and palm oil production. GDP and palm oil production are indicators of economic size. The study includes the variables of import tax, colony, 
and common language, which can influence the trade between countries. The last two variables are export tax and biomass regulation as the focus variables on this research. For export, the tax will be in the form of a relative export tax of CPO to RPO export tax.

The methods for analysis are OLS and PPML. OLS gravity equation is a good linear model that has enough to explain the policy implication. PPML gravity equation can overcome zero trade issues that usually become an issue for natural logarithm in OLS. Both estimators show less bias, although for OLS still found the heteroscedasticity in $\mathrm{CPO}$ estimation. The results obtained from OLS and PPML estimators show that biomass regulation has a negative impact on RPO products that means the issuing biomass regulation in the EU can reduce the trade of RPO to the EU. Biomass regulation does not show a significant coefficient in $\mathrm{CPO}$ products. The export tax $\mathrm{CPO}$ seems to have a positive impact on RPO, which means that when the CPO export tax increases, the importing countries will import more on RPO product.

\section{Recommendations}

The effect described by the estimation results shows that some potentials can be developed by policyholders to add more competitive value trade. Exporters could produce more on CPO instead of RPO to reduce the loss of trade on RPO in the EU since biomass regulation issued. Moreover, exporters should produce better palm oil production to meet the standard requirements of GHG emission reduction. The new technology should be applied to increase productivity and produce palm oil with less GHG emissions. The increase of export tax on CPO will create a benefit for RPO exporter, as well as to prevent the outflow of CPO. The CPO export tax will trigger the palm oil-exporting country to produce and export more on RPO. The biodiesel production by the exporters could be a trade chance of recent trends to counter climate change problems while it absorbs $\mathrm{CPO}$ products by themselves.

\section{REFERENCES}

[EPOA] European Palm Oil Alliance. 2016. Palm Oil Consumption. European Palm Oil Alliance. https://www.palmoilandfood.eu/en/palm-oilconsumption [29 Oct 2018].

[EU] European Union. 2009. Directive 2009/28/EC of the European Parliament and of the Council. Official Journal of The European Union. EURLexeur-lex.europa.eu [29 Oct 2018].

[EU] European Union. 2009. Directive 2009/30/EC of the European Parliament and of the Council. Official Journal of The European Union. EURLexeur-lex.europa.eu [29 Oct 2018].

[USDA] United States Department of Agriculture. 2013. Biofuels Annual: EU Biofuels Annual 2013. Global Agricultural Information Network. USDA Foreign Agricultural Service. http://gain. fas.usda.gov/Pages/Default.aspx [29 Oct 2018].

[USDA] United States Department of Agriculture. 2017. Biofuels Annual: EU Biofuels Annual 2017. Global Agricultural Information Network. USDA Foreign Agricultural Service. http://gain. fas.usda.gov/Pages/Default.aspx [29 Oct 2018].

[USDA] United States Department of Agriculture. 2018. Production for Indonesia. United States Department of Agriculture. https://apps.fas. usda.gov/psdonline/ app/index.html\#/app/home/ statsByCountry [29 Oct 2018].

Anderson JE, van Wincoop E. 2003. Gravity with gravitas: A solution to the Border Puzzle. The American Economic Review 93 (1): 170-192.

Anderson JE. 1979. A theoretical foundation for the gravity equation. American Economic Association 69 (1): 106-116. https://doi. org/10.1257/000282803321455214.

Ayatollah KAR, Abdullah R, Balu N, Husin N, Idris NAN, Ahmad SM, Hashim N. 2014. Impact of the new CPO export tax structure on the Malaysian refining industry. Oil Palm Industry Economic Journal 14 (2).

Bosse EVD. 2013. Tariffs, non-tariff measures and imports: A comparison of econometric approaches to estimate the gravity equation. thesis.eur.nl > pub > Eline-van-den-Bosse [15 Februari 2020].

Breusch TS, Pagan AR. 1979. A simple test for heteroscedasticity and random coefficient variation. Econometrica 47 (5): 1287-1294. https://doi.org/10.2307/1911963.

Effendi Y. 2016. Impacts of export tax of cocoa beans on Indonesian Economy. Pelita Perkebunan 32 (1) 2016: 67-81.https://doi.org/10.22302/iccri. jur.pelitaperkebunan.v32i1.170.

Hasibuan AM, Sayekti AL. 2018. Export tax policy in Indonesia: The impacts on competitiveness and price integration of cocoa products. Journal of Social Sciences and Humanities 26 (1): 535- 
552.

Kareem OI. 2016. Food safety regulations fish trade: Evidence from European Union-Africa trade relations. Journal of Commodity Markets 2 (2016): 18-25. http://dx.doi.org/10.1016/j. jcomm.2016.07.002.

Kuo TC, Vincent A. 2018. Assesing the changes in international trade of marine fishes under CITES regulations - a case study of seahorses. Marine Policy 88 (2018): 48-57. https://doi. org/10.1016/j.marpol.2017.10.031.

Martinez-Zarzoso I. 2013. The log of gravity revisited. Applied Economics 45 (3): 311-327. http:// dx.doi.org/10.1080/00036846.2011.599786.

Mayer T, Zignago S. 2006. Notes on CEPII's distances measures.http://www.cepii.fr/distance/ noticedist_en.pdf [15 Feb 2020].

Obado J, Syaukat Y, Siregar H. 2009. The impacts of export tax on the Indonesian crude palm oil industry. Journal of International Society for Southeast Asian Agricultural Sciences 15(2): 107-118. https://www.researchgate.net/ publication/228461400.

Rajcaniova M, Drabik D, Ciaian P. 2013. How policies affect international biofuel price linkages. Energy Policy 59 (2013): 857-865. http://dx.doi. org/10.1016/j.enpol.2013.04.049.

Rifin A. 2010. The effect of export tax on Indonesia's crude palm oil (CPO) export competitiveness. ASEAN Economic Bulletin 27(2): 173-184. https://doi.org/10.1355/ae27-2b.

Rifin A. 2014. The effect of crude palm oil export tax on export and prices. ASEAN Journal of Economics, Management and Accounting 2(1\&2): 82-95.

Rifin A. 2014. The effect of progressive export tax on Indonesian palm oil industry. Oil Palm Industry Economic Journal 14 (1)/March 2014.

Rizwan M, Rahuman H. 2014. The co-operative benefits of Malaysia and Indonesia in palm oil. Oil Palm
Industry Economic Journal 14 (1)/March 2014.

Rude J, An H. 2015. Explaining grain and oilseed price volatility: The role of export restrictions. Journal of Food Policy 57 (2015): 83-92. http://dx.doi. org/10.1016/j.foodpol.2015.09.002.

Salvatore D. 2013. International Economics: Eleventh edition. New York: John Wiley \& Sons.

Sheng Y, Tang HC, Xu X. 2014. The impact of the ACFTA on ASEAN-PRC trade: estimates based on an extended gravity model for component trade. Applied Economics 46 (19): 2251-2263. http://dx.doi.org/10.1080/00036846.2014.8996 76.

Sheperd B. 2016. The gravity model of international trade: A user guide (an update version). United Nations publication. ST/ESCAP/2766.

Silva JMCS, Tenreyro S. 2006. The log of gravity model. The Review of Economics and Statistics 88 (4): 641-658. https://doi.org/10.1162/rest.88.4.641.

Silva JMCS, Tenreyro S. 2011. Further simulation evidence on the performance of the poisson pseudo-maximum likelihood estimator. Economics Letter 112 (2011): 220-222. doi:10.1016/j.econlet.2011.05.008.

Timilsina GR, ShrestaA.2010. Biofuels: markets, targets and impacts. Development Research Group Environment and Energy Team. Washington: The World Bank.https://doi.org/10.1596/18139450-5364.

Wang Z, Zhang B, Zeng H. 2016. The effect of environmental regulation on external trade: empirical evidences from Chinese economy. Journal of Cleaner Production 114 (2016): 55-61. http://dx.doi.org/10.1016/j.jclepro.2015.07.148.

Yang S, Martinez-Zarzoso I. 2014. A panel data analysis of trade creation and trade diversion effects: The case of ASEAN-China free trade area. China Economic Review 29 (2014): 138-151. http:// dx.doi.org/10.1016/j.chieco.2014.04.002. 